\title{
Sosialisasi Pendampingan Hukum Terhadap Anak Asuh di SOS Children Villages
}

\author{
Nila Trisna \\ Jurusan Ilmu Hukum, Universitas Teuku Umar \\ Email: nilatrisna@utu.ac.id
}

Submitted: 26 November 2019 Revised: 06 Desember 2019 Accepted: 08 Desember 2019

\begin{abstract}
Law No. 35 of 2014 concerning protection of children also guarantees the fulfillment of children's rights to survival, growth and development and is entitled to protection from violence and discrimination. Fulfillment of the rights of basic needs and protection for children in the scope of West Aceh has not yet been fully implemented. The process of conducting the socialization was carried out by the method of exposure and discussion of legal counseling materials about the role and obligations of the Government in providing legal protection to children who need legal assistance. The participation of all parties in paying attention to the protection of children is one thing that is very urgent. Given cases involving children in conflict with the law both as perpetrators and victims, often ignoring the rights of children who should be protected by laws and regulations. This is what needs to be done by all parties to encourage the West Aceh District Government to immediately give birth a Qanun on Child Protection. So that with regulations specifically related to child protection, children's rights are guaranteed by law.
\end{abstract}

Keyword: Legal Assistance, Foster Child

\begin{abstract}
Abstrak
Undang-Undang Nomor 35 Tahun 2014 Tentang perlindungan terhadap anak menjamin pemenuhan hak anak atas keberlangsungan hidup, tumbuh dan berkembang serta berhak atas perlindungan dari kekerasan dan diskriminasi. Pemenuhan hak kebutuhan dasar dan perlindungan bagi anak di lingkup Aceh Barat belum sepenuhnya terlaksana. Proses pelaksanaan sosialisasi dilakukan dengan metode pemaparan dan diskusi terhadap materi penyuluhan hukum tentang peran dan kewajiban Pemerintah dalam memberikan perlindungan hukum terhadap anak-anak yang membutuhkan bantuan hukum. Peran serta semua pihak dalam memberikan perhatian terhadap perlindungan anak merupakan satu hal yang sangat mendesak. Mengingat kasus-kasus yang melibatkan anak berkonflik dengan hukum baik sebagai pelaku maupun korban, sering mengabaikan hak-hak anak yang seharusnya dilindungi oleh peraturan perundang-undangan. Hal ini yang perlu dilakukan oleh semua pihak untuk mendorong Pemerintah Kabupaten Aceh Barat untuk segera melahirkan Qanun Tentang Perlindungan Anak. Sehingga dengan adanya regulasi secara khusus terkait perlindungan anak maka hak-hak anak dijamin oleh Undang-Undang
\end{abstract}

Kata Kunci: Pendampingan Hukum, Anak Asuh

\section{PENDAHULUAN}

Dalam Pasal 34 ayat 1 (satu) UUD 1945 menyebutkan bahwa: Fakir miskin dan anak terlantar dipelihara oleh negara. Hal ini menjelaskan bahwa Negara mempunyai tanggung jawab untuk melindungi khususnya anak-anak yang terlantar, dan sekaligus mempunyai tanggung jawab untuk memelihara hak-hak anak terlantar tersebut. Selain itu, negara melalui Kementerian Sosial mengeluarkan pula Undang-Undang Nomor 35 
Tahun 2014 juga menjamin perlindungan terhadap hak anak atas keberlangsungan hidup, tumbuh dan berkembang serta berhak atas perlindungan dari kekerasan dan diskriminasi.

Selama ini upaya melakukan perlindungan hukum belum terlaksana secara maksimal. Karena fakta yang terjadi di lapangan, perlindungan hukum anak hanya dititik beratkan pada lembaga pemerintah atau swasta. Sehingga hal tersebut hanya menyasar pada hal-hal mendasar saja tidak sepenuhnya mengena pada hakikat sebenar-benarnya dalam melakukan perlindungan hukum bagi anak. Bisa dikatakan beberapa stakeholders di antaranya; pemerintah daerah, pihak kepolisian, akademisi, tokoh masyarakat dan masyarakat setempat merasa acuh tak acuh seolah permasalahan yang dialami anak sudah ada lembaga atau pihak yang menanganinya.

Sesungguhnya urusan anak bukan hanya milik satu kementerian/ lembaga, atau sektor lembaga tertentu. Jadi ketika bicara tentang hak anak, harus melibatkan berbagai stakeholders dari bermacam kepentingan sebagai upaya perlindungan anak perlu adanya pengkajian lebih lanjut terkait efektivitas penegakan hukum dari UU yang berlaku.
Pemenuhan hak kebutuhan dasar dan perlindungan bagi anak di lingkup Aceh Barat belum sepenuhnya terlaksana. Jika selama ini ada kasus yang menyebabkan anak menjadi bagian dari korban kekerasan rumah tangga, korban asusila atau saksi dari beberapa tindakan kriminal belum ada perhatian khsusus dari pemerintah daerah, pihak kepolisian dan tokoh masyarakat untuk memberikan pemenuhan hak kebutuhan psikologis (rasa aman) dan perlindungan hukum bagi anak.

Anak sebagai generasi penerus bangsa yang secara alami masih sangat membutuhkan perhatian karena kedudukannya masih sangat rawan untuk berbagai hambatan dan tantangan dalam kehidupannya tentunya mendapat tempat yang paling penting untuk perlindungan oleh negara khususnya dalam hal ini pemerintah pusat dan pemerintah daerah yang bertujuan agar dalam proses tumbuh kembangnya anak menjadi seseorang yang cerdas, sehat, kuat dan dapat diandalkan. Dalam faktanya tidak semua anak mendapatkan kasih sayang secara utuh dan menyeluruh dari orang tua kandung atau tidak semua anak dilahirkan dari keluarga yang memberikan perhatian secara penuh kepada anak anak mereka dan tidak semua orang tua dapat memberikan secara baik apa yang dibutuhkan 
untuk tumbuh kembang anak. Maka dari itu disinilah dibutuhkan peran Negara untuk pemenuhan kebutuhan dan perlindungan anak, karena anak diposisikan sebagai seseorang yang masih sangat lemah.

Mengacu kepada amanat dalam undang-undang dasar sebagai landasan yuridis landasan yuridis terhadap pelaksanaan perlindungan anak menegaskan bahwa Negara menjamin atas pemenuhan keberlangsungan hidup, tumbuh dan kembang serta perlindungan terhadap kekerasan dan diskriminasi terhadap anak. Sebagaimana didalam undang undang nomor 35 tahun 2014 tentang perubahan undang undang nomor 23 tahun 2002 tentang perlindungan anak atau sebagaimana disebut UU 35 tahun 2014.

Peran serta semua pihak dalam memberikan perhatian terhadap perlindungan anak merupakan satu hal yang sangat mendesak. Mengingat kasus-kasus yang melibatkan anak berkonflik dengan hukum baik sebagai pelaku maupun korban, sering mengabaikan hakhak anak yang seharusnya dilindungi oleh peraturan perundang-undangan. Hal ini yang perlu dilakukan oleh semua pihak untuk mendorong Pemerintah Kabupaten Aceh Barat untuk segera melahirkan Qanun Tentang
Perlindungan Anak. Sehingga dengan adanya regulasi secara khusus terkait perlindungan anak maka hak-hak anak dijamin oleh Undang-Undang.

\section{METODE PELAKSANAAN}

Materi yang diberikan dalam kegiatan sosialisasi ini adalah mekanisme Pendampingan Hukum Terhadap Anak Asuh Di SOS Children's Villages. Adapun tujuan dilakukan sosialisasi ini adalah untuk memberikan perlindungan hukum terhadap anak-anak asuh yang terlibat dengan permasalahan hukum. Sehingga anak-anak asuh ini memperoleh hak-hak yang semestinya mereka dapatkan sebagaimana terdapat didalam UU Perlindungan Anak.

Adapun yang menjadi sasaran dalam kegiatan ini adalah anak-anak asuh yang ada di SOS Children's Villages.

\section{HASIL DAN PEMBAHASAN}

Selama ini upaya melakukan perlindungan hukum belum terlaksanaan secara maksimal. Karena fakta terjadi di lapangan perlindungan hukum anak hanya dititik beratkan hanya pada lembaga pemerintah atau swasta. Sehingga hal tersebut menjadi perlindungan hukum hanya menyasar hal-hal mendasar saja tidak sepenuhnya mengena pada hakikat sebenar- 
benarnya dalam melakukan perlindungan hukum bagi anak. Bisa dikatakan beberapa stakeholders di antaranya; pemerintah daerah, pihak kepolisian, akademisi, tokoh masyarakat dan masyarakat setempat merasa acuh tak acuh seolah permasalahan yang dialami anak sudah ada lembaga atau pihak yang menanganinya.

Sesungguhnya urusan anak bukan hanya milik satu kementerian lembaga, atau sektor lembaga tertentu. Jadi ketika bicara tentang hak anak, harus melibatkan berbagai stakeholder dari bermacam kepentingan sebagai upaya perlindungan anak perlu adanya pengkajian lebih lanjut terkait efektivitas penegakan hukum dari UU yang berlaku.

Pemenuhan hak kebutuhan dasar dan perlindungan bagi anak di lingkup Aceh Barat belum sepenuhnya terlaksana. Jika selama ini ada kasus yang menyebabkan anak menjadi bahagian dari korban kekerasan rumah tangga, korban asusila atau saksi dari beberapa tindakan kriminal belum ada perhatian khsusus dari pemerintah daerah, pihak kepolisian dan tokoh masyarakat untuk memberikan pemenuhan hak kebutuhan psikologis (rasa aman) dan perlindungan hukum bagi anak.

Adapun bentuk pendampingan hukum dilakukan terhadap anak yang berkonflik dengan hukum baik sebagai pelaku maupun korban dilakukan dengan konsultasi hukum terkait kasus yang mereka hadapi, serta mencari solusi dan pemecahan, sehingga persoalan tersebut bisa terselesaikan dengan cepat.

Peran serta semua pihak dalam memberikan perhatian terhadap perlindungan anak merupakan satu hal yang sangat mendesak. Mengingat kasus-kasus yang melibatkan anak berkonflik dengan hukum baik sebagai pelaku maupun korban, sering mengabaikan hakhak anak yang seharusnya dilindungi oleh peraturan perundang-undangan. Hal ini yang perlu dilakukan oleh semua pihak untuk mendorong Pemerintah Kabupaten Aceh Barat untuk segera melahirkan Qanun Tentang Perlindungan Anak. Sehingga dengan adanya regulasi secara khusus terkait perlindungan anak maka hak-hak anak dijamin oleh Undang-Undang.

Proses pelaksanaan sosialisasi dilakukan dengan metode pemaparan dan diskusi terhadap materi penyuluhan hukum tentang peran dan kewajiban Pemerintah dalam memberikan perlindungan hukum terhadap anak-anak yang membutuhkan bantuan hukum. Metode sosialisasi dikombinasikan dengan memanfaatkan media laptop dan LCD untuk menampilkan 
visualisasi kasus-kasus tentang anak yang berkonflik dengan masalah hukum, serta menampilkan juga power point mengenai materi tentang perlindungan hukum.
Berikut disajikan pada gambar 1 pada saat menyampaikan materi kegiatan yang berhubungan perlindungan hukum dan membangun koordinasi dengan berbagai stakeholders

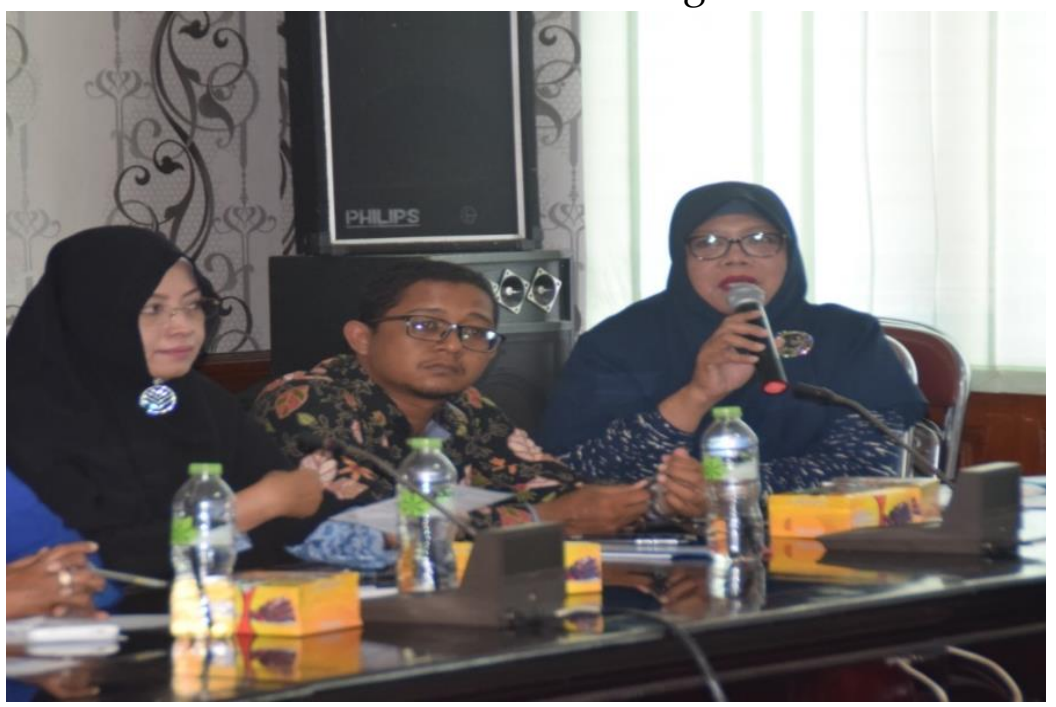

Gambar 1. Acara SOS Desa Taruna bersama Stakeholders Meeting and Dialog

\section{PENUTUP}

Peranan pemerintah dalam memberikan perlindungan kepada seluruh warga negara adalah tanggung jawab mutlak sebagaimana terdapat di dalam Alenia ke IV UUD 1945.

Dalam rangka menciptakan keadilan hukum sebagaimana terdapat di dalamPasal 27 ayat 1 (satu) UUD 1945, Bahwa setiap Warga Negara bersamaan kedudukannya di dalam Hukum dan Pemerintahan dengan tidak ada kecualinya, termasuk perlindungan hukum terhadap anak-anak yang berkonflik dengan hukum, berhak untuk mendapatkan pendampingan hukum terutama anak-anak yang tidak mempunyai biaya dalam berperkara.

Prinsip Equality Before The Law harus diwujudkan dalam sebuah Negara Hukum sebagaimana terdapat dalam Pasal 1 (satu) ayat 3 (tiga) UUD 1945, menjadi sesuatu hal yang tidak dapat ditawar lagi keberadaannya dan mutlak terpenuhi. Berdasarkan hasil yang diperoleh dalam kegiatan pengabdian masyarakat ini, adapun saran yang bisa disampaikan adalah sebagai berikut:

Anak merupakan generasi penerus bangsa adalah bagian dari generasi muda sebagai salah satu 
sumber daya manusia yang merupakan potensi dan penerus cita-cita perjuangan bangsa, Dengan demikian, maka anak adalah komponen penting dari bangsa Indonesia sehingga kedudukannya adalah sebagai pihak yang wajib dilindungi.

Undang-undang Nomor 11 Tahun 2012 tentang Sistem Peradilan Anak juga menjelaskan bahwa anak memiliki peran strategis yang secara tegas dinyatakan bahwa negara menjamin hak setiap anak atas kelangsungan hidup, tumbuh, dan berkembang serta atas pelindungan dari kekerasan dan diskriminasi. Oleh karena itu, kepentingan terbaik bagi anak patut dihayati sebagai kepentingan terbaik bagi kelangsungan hidup umat manusia.

Peran serta semua pihak dalam memberikan perhatian terhadap perlindungan anak merupakan satu hal yang sangat mendesak. Mengingat kasus-kasus yang melibatkan anak berkonflik dengan hukum baik sebagai pelaku maupun korban, sering mengabaikan hakhak anak yang seharusnya dilindungi oleh peraturan perundang-undangan. Hal ini yang perlu dilakukan oleh semua pihak untuk mendorong Pemerintah Kabupaten Aceh Barat untuk segera melahirkan Qanun Tentang Perlindungan Anak. Sehingga dengan adanya regulasi secara khusus terkait perlindungan anak maka hak-hak anak dijamin oleh Undang-Undang.

\section{DAFTAR PUSTAKA}

Lilik Mulyadi, 2005. Putusan Hakim Dalam Hukum Acara Pidana, Bandung, PT. Cipta Aditya Bakti.

Marlina, 2009. Peradilan Pidana Anak $D i$ Indonesia Pengembangan Konsep Diversi dan Restorative Justice , Bandung, Refki Aditama.

M. Yahya Harahap, 2002. Pembahasan Permasalahan dan Penerapan KUHAP, Jakarta, Sinar Grafika.

Soetodjo, Wagiati, 2006. Hukum Pidana Anak. Bandung, PT. Refika Aditama.

Undang-Undang Dasar Negara Republik Indonesia Tahun 1945 Undang-Undang Nomor 8 Tahun 1981 Tentang Kitab UndangUndang Hukum Acara Pidana

Undang-Undang Nomor 18 Tahun 2003 tentang Advokat

Undang-Undang Nomor 48 Tahun 2009 tentang Kekuasaan Kehakiman.

Undang-undang Nomor 11 Tahun 2012 tentang Sistem Peradilan Anak

Undang-Undang Nomor 35 Tahun 2014 tentang Perlindungan Anak 